\section{Family psychosocial characteristics, tobacco, alcohol, and other drug use, and teenage pregnancy}

\author{
Características psicossociais familiares e uso de \\ tabaco, álcool e outras drogas relacionadas \\ à gravidez na adolescência
}

\section{Características psicosociales familiares y el uso del tabaco, alcohol y otras drogas relacionadas con el embarazo en la adolescencia}

Camilia Susana Faler 1

Sheila Gonçalves Câmara 1,2

Denise Rangel Ganzo de Castro Aerts 1,3

Gehysa Guimarães Alves 1,4

Jorge Umberto Béria 1,3

\section{Programa de Pós-graduação em Saúde Coletiva, \\ Universidade Luterana do Brasil, Canoas, Brasil. \\ 2 Departamento de Psicologia, Universidade Federal de \\ Ciências da Saúde de Porto Alegre, Porto Alegre, Brasil. ${ }_{3}^{3}$ Curso de Medicina, Universidade Luterana do Brasil, Canoas, Brasil. 4 Curso de Enfermagem, Universidade Luterana do Brasil, Canoas, Brasil. \\ Correspondence C. S. Faler Programa de Pós-graduação em Saúde Coletiva, Universidade Luterana do Brasil. \\ Rua Oswaldo Cruz 30, Três Palmeiras, RS 99675-000, Brasil.}

camilafaler@yahoo.com.br

\begin{abstract}
The aim of this study was to analyze associations between demographic factors, family psychosocial characteristics, tobacco, alcohol, and other drug use, and adolescent motherhood. This was a case-control study in Porto Alegre, Rio Grande do Sul State, Brazil, with 431 adolescents 14 to 16 years of age who gave birth in 2009 (cases) and 862 adolescents who had never given birth (controls). Three-stage hierarchical logistic regression was performed (demographic, family psychosocial, and lifestyle variables). Lower economic class, not having lived with the parents from 10 to 14 years of age (OR =1.67; 95\%CI: 1.12-2.48), having taken care of other children (OR $=1.42$; 95\%CI: 1.09-1.87), siblings who had children before 20 years of age (OR $=1.56$; 95\%CI: 1.192.06), having tried smoking $(O R=1.94 ; 95 \% C I$ 1.35-2.78), and having arrived home intoxicated $(O R=1.67 ; 95 \% C I: 1.12-2.48)$ were associated with adolescent motherhood. Greater attention should be given to family relations in association with tobacco and alcohol consumption, since the use of these substances is associated with adolescent motherhood.
\end{abstract}

Pregnancy in Adolescence; Alcohol Drinking; Smoking; Street Drugs

\section{Resumo}

O objetivo foi estudar a associação entre fatores demográficos, características psicossociais familiares, uso de tabaco, álcool e outras drogas e a gravidez na adolescência. Estudo de casocontrole com 431 adolescentes, com idades entre 14 e 16 anos, de Porto Alegre, Rio Grande do Sul, Brasil, que tiveram filhos em 2009 (casos), e 858 adolescentes sem filhos (controles). A regressão logística hierárquica foi realizada em três etapas (variáveis demográficas, variáveis psicossociais familiares e variáveis de estilo de vida). A menor inserção econômica, não ter morado com os pais entre 10 e 14 anos ( $R C=1,67$; IC95\%: 1,12-2,48), experiência no cuidado de crianças $(R C=1,42$; IC95\%: 1,09-1,87), irmãos que tiveram filhos antes dos 20 anos ( $R C=1,56$; IC95\%: 1,19-2,06), experimentação de tabaco $(R C=1,94$; IC95\%: 1,35-2,78) e já ter chegado em casa embriagada $(R C=1,67 ;$ IC95\%: 1,12-2,48) associaram-se à gravidez na adolescência. Maior atenção deve ser dada às relações familiares em relação ao consumo de tabaco e álcool, considerando que o uso destas substâncias se associam à gravidez na adolescência.

Gravidez na Adolescência; Consumo de Bebidas Alcoólicas; Hábito de Fumar; Drogas Ilícitas 


\section{Introduction}

According to the Brazilian Institute of Geography and Statistics (IBGE; http://www.ibge.gov.br), the country's female population 10 to 19 years of age totaled more than 16 million in the year 2010 . Changes in teenagers' sexual behavior patterns merit special attention, due to the repercussions, including early pregnancy 1 . Teenage pregnancy has become a public health problem, since it potentially leads to physical, emotional, social, and economic problems for both the mother and infant 2,3,4.

In Brazil, the highest teenage pregnancy rates occur in low-income groups, and there is an association between high adolescent parity and low schooling 5,6 .

According to a study on risk behaviors in a young population, extreme vulnerability due to involvement in a context of violence increases the association between early pregnancy and other risk behaviors 7 . Such living conditions facilitate different forms of family organization in which both parents are not always present, which can limit opportunities for family bonds and support, thereby further increasing vulnerability and risk exposure $8,9,10$. This context of lack of family protection places youth at even greater vulnerability and exposes them to various factors, including early pregnancy. A typical culture is established, potentially more lenient towards adolescents' social activity, besides representing a model for family configuration and lifestyles 11,12.

In low-income settings, teenage pregnancy can be permeated by positive meanings, where it is taken for granted as a life choice associated with the perception of otherwise limited options and opportunities 3,13. Motherhood can be seen by the teenage girl as an attempt to ensure a stable relationship with the male partner, to acquire independence from her nuclear family, and to achieve an effective feminine identity, in addition to consolidating a social role that she sees as within her reach $14,15,16$. In a society that culturally assumes marriage as a prior condition for establishing a family, the adolescent girl's stable relationship with the child's father appears to contribute to the representation of early pregnancy as a natural and desirable event 17 . Trans-generational issues such as a history of early motherhood in the family and the girl's caring for other children during childhood have also been associated with adolescent motherhood 18,19,20,21,22.

As for lifestyles, socialization means that the values, attitudes, and beliefs of the social context, translated in family relations and behaviors, are assumed as the possible and natural way of life 23. Thus, tobacco, alcohol, and drug use in the family represents a model to be followed by the adolescents 24,25 . Studies show that trying alcohol and tobacco for the first time often occurs during adolescence, many times within the family setting 10,26,27,28. Research points to substance use by the family and by adolescent girls as a factor associated with early motherhood 29,30.

There are various types of families, and relations among their members determine the group's protective or risk roles 24 . It is important to consider the socioeconomic and cultural setting to which the family belongs, the family socialization processes, and the parenting styles, since these are usually the backdrop for the phenomenon of adolescent motherhood. The current study thus aimed to analyze the association between demographic factors, family psychosocial characteristics, and tobacco, alcohol and other drug use and adolescent motherhood.

\section{Method}

The study used a case-control design. Cases were defined as adolescent mothers. For each case, two controls were selected among adolescents who had never given birth and lived in the same neighborhood. The target population for cases consisted of all adolescents girls from 14 to 16 years of age who had given birth and lived in Porto Alegre, Rio Grande do Sul State, Brazil, in 2009.

The point of departure for calculating the sample size was the number of mothers 14 to 16 years of age in 2006 (860 cases) according to the Information System on Live Births (SINASC) in Porto Alegre. It was assumed that this same number of deliveries occurred in 2009. The study used Epi Info (Centers for Disease Control and Prevention, Atlanta, USA) with significance set at 0.05 , study power $80 \%$, case/control ratio $1: 2$, and $20 \%$ minimum exposure rate among controls, and calculated 415 cases and 830 controls.

The Surveillance Team on Vital Events of the Division on Health Surveillance provided a list of all adolescents 14 to 16 years of age that gave birth in 2009. This allowed identifying the adolescent mothers and their addresses.

As the case selection strategy, initially for every two adolescents, one was picked for the visit. If her household was not located, the case was replaced by the adolescent immediately before or after her on the list. After the interview with the case was obtained, the respective controls were searched for among the households in the case's neighborhood. One side of the street was picked, and the selection alternated houses one on each 
side of the street until two adolescents were found who were the same age as the case (plus or minus a year), but who had never given birth.

A questionnaire was developed especially for the project, Factors Associated with Adolescent Pregnancy: a Case-Control Study in 14-16-YearOld Adolescents in Porto Alegre, based on a literature review and other studies on adolescent sexuality 31,32 .

The study used demographic data on the adolescent (age, skin color, religion, economic class, and schooling), lifestyle (history of use of tobacco, alcohol, and/or illegal drugs, intoxication, family's reaction to intoxication, family member with alcohol or drug-related problems), and family's psychosocial characteristics (raised by biological or social mother, loss of biological mother, schooling of the adolescent's mother, persons with whom the adolescent lived from 10 to 14 years of age, caregiver during most of the adolescent's life, experience caring for other children, age of the adolescent's mother at first childbirth, and siblings who had children before 20 years of age).

Data collection lasted from August 2009 and to December 2010. The data were collected by female university students enrolled in the health sciences who received training and weekly followup during meetings with the entire project team. The questionnaire was completed by the interviewers and later processed using the TELEform system (Autonomy Inc., San Francisco, USA). This software replaces manual data entry with an automatic scanning process that transposes the data to a database in a statistical package.

The project team conducted the quality control, both in performing the interviews and for the precision of the scanned data. The data were analyzed with SPSS 18.0 (SPSS Inc., Chicago, USA).

The data analysis began with bivariate analyses between the outcome and the study factors. The multivariate logistic regression included the variables that originally presented $\mathrm{p}$-values < 0.20 . The logistic regression was performed according to a three-stage hierarchical model. The demographic variables were introduced in the first stage, and only those with $\mathrm{p}<0.10$ were kept in the model. Family psychosocial variables were introduced in the second stage, using the same criterion to be kept in the regression. The third stage included lifestyle variables. Significant associations were defined as those with p-values < 0.05 in the stage in which they were introduced in the model.

The research project was approved by the Ethics Research Committee of Universidade Luterana do Brasil (ULBRA; case no. 2008-095H) and the Porto Alegre Municipal Health Secretariat (case no. 001.017587.09.3). The parents or guardians signed a free and informed consent form attesting that the adolescent agreed to participate in the study.

\section{Results}

Table 1 shows the main demographic characteristics of cases and controls. No significant differences were found between cases and controls for race/color or religion; of the total, there was a slight predominance of adolescents with selfreported white race/skin color, and the majority were Catholic. As for the other variables, the controls showed higher economic class and more schooling and were younger on average than cases $(\mathrm{p}<0.05)$.

As for family psychosocial characteristics and lifestyle, of the 15 respective variables, only four were statistically associated with adolescent motherhood: loss of biological mother, schooling of the adolescent's biological or social mother, the adolescent's main lifetime caregiver (Table 2), and family history of drug problems (Table 3 ).

In the hierarchical logistic regression model, variables with $\mathrm{p}<0.20$ in the stage in which they were introduced remained in the regression in order to control for possible confounding. According to the final model (Table 4), six factors were significantly associated with adolescent motherhood $(\mathrm{p}<0.05)$.

Girls belonging to economic classes $\mathrm{C}$ and $\mathrm{D}+\mathrm{E}$ showed three times higher odds of adolescent motherhood than those from class B. Likewise, those that had not lived with one or both parents when they were 10 to 14 years old, those with experience in caring for other children, and those whose siblings had children before they were 20 showed higher odds of adolescent motherhood.

Finally, in relation to substance use, girls that had tried smoking showed twofold higher odds of motherhood than those who had not; having come home intoxicated was also associated with increased odds of adolescent motherhood.

\section{Discussion}

The current study shed light on the reality of adolescent mothers in their life setting, that is, in the place where they lived and their living conditions. The fact that the sample of cases was selected from a list of all live births, which could have been from anywhere in the city and thus represented socioeconomic and cultural diversi- 
Demographic characteristics of adolescent girls with and without children. Porto Alegre, Rio Grande do Sul State, Brazil, 2009.

\begin{tabular}{|c|c|c|c|c|c|c|}
\hline \multirow[t]{2}{*}{ Demographic variables } & \multicolumn{2}{|c|}{ Cases $(\mathrm{N}=431)$} & \multicolumn{2}{|c|}{ Controls $(\mathrm{N}=858)$} & \multirow[t]{2}{*}{ OR $(95 \% \mathrm{Cl})$} & \multirow[t]{2}{*}{ p-value } \\
\hline & $\mathrm{n}$ & $\%$ & $\mathrm{n}$ & $\%$ & & \\
\hline \multicolumn{7}{|l|}{ Age (years) } \\
\hline 14 & 54 & 12.6 & 338 & 39.9 & 1.00 & $<0.001$ \\
\hline 15 & 134 & 31.4 & 293 & 34.6 & $2.27(1.71-3.02)$ & \\
\hline 16 & 240 & 56.1 & 217 & 25.6 & $3.81(2.93-4.95)$ & \\
\hline \multicolumn{7}{|l|}{ Race/Color } \\
\hline White & 206 & 49.2 & 418 & 50.8 & 1.00 & 0.588 \\
\hline Non-white & 213 & 50.8 & 405 & 49.2 & $1.064(0.84-1.35)$ & \\
\hline \multicolumn{7}{|l|}{ Religion } \\
\hline Non-Catholic & 66 & 17.4 & 148 & 19.9 & 1.00 & 0.111 \\
\hline Catholic & 165 & 43.5 & 352 & 47.3 & $1.03(0.81-1.31)$ & \\
\hline None & 148 & 39.1 & 244 & 22.8 & $1.22(0.96-1.55)$ & \\
\hline \multicolumn{7}{|l|}{ Economic class } \\
\hline B & 20 & 4.7 & 51 & 6.0 & 1.00 & $<0.001$ \\
\hline C & 334 & 77.9 & 744 & 87.1 & $1.09(0.75-1.61)$ & \\
\hline$D+E$ & 75 & 17.5 & 59 & 6.9 & $1.98(1.33-2.96)$ & \\
\hline \multicolumn{7}{|l|}{ Schooling } \\
\hline Middle School & 42 & 12.7 & 33 & 20.1 & 1.00 & 0.021 \\
\hline Primary School & 290 & 87.3 & 131 & 79.9 & $1.73(1.05-2.86)$ & \\
\hline
\end{tabular}

95\% Cl: 95\% confidence interval; OR: odds ratio.

ty, allowed power for generalization. Some studies have limited the focus to adolescent students, thereby limiting the possibility of extrapolation, since enrollment in school can be considered a protective factor against various teenage risk behaviors 33,34. The current study's results can thus contribute to interventions targeting the prevention of teenage pregnancy, relating family lifestyles to the issue.

Both the cases and the controls lived in peripheral low-income areas of Porto Alegre. However, economic class was higher on average in the controls. Some studies have shown an association between lower economic status and teenage pregnancy 35,36,37. In Santo André, São Paulo, a study comparing adolescent mothers living in four areas with different degrees of social exclusion found that higher fertility was associated with worse socioeconomic conditions 35 . According to a study comparing adolescent mothers and young adult mothers in Maceió, Alagoas State, even though both groups showed low monthly family income, per capita income was lower in the adolescent group 36 . In São Luís, Maranhão State, a study on differences in socioeconomic characteristics between adolescents under 18 years of age, 18 to 19 , and women over this age found that the under-18 and 18-to-19-year groups had lower mean family income 37 .

Teenage pregnancy is associated with adolescent girls not living with their parents during puberty, from 10 to 14 years of age. The association between living away from home and adolescent motherhood was shown in a review study of adolescents living on the streets, where a recurrent finding was that young women who had lived away from home for longer periods of time were more prone to becoming pregnant 38 . As for the reasons for not living with their families, domestic violence and precarious family conditions are key factors and reflect socioeconomic exclusion 39. However, these findings should be interpreted with caution, since the study's target population consisted of girls living on the streets, which was not the case of the adolescents analyzed in the current study. At any rate, one can assume that the need to live away from home indicates family problems (although the current study did not explore reasons for leaving home).

The fact that taking care of other children was associated with adolescent motherhood in the current study could be understood based on differences in socialization between the male and female genders. Gender is a social construction 
Family psychosocial characteristics of adolescent girls with and without children. Porto Alegre, Rio Grande do Sul State, Brazil, 2009.

\begin{tabular}{|c|c|c|c|c|c|c|}
\hline \multirow[t]{2}{*}{ Family characteristics } & \multicolumn{2}{|c|}{ Cases $(\mathrm{N}=431)$} & \multicolumn{2}{|c|}{ Controls $(\mathrm{N}=858)$} & \multirow[t]{2}{*}{ OR $(95 \% \mathrm{Cl})$} & \multirow[t]{2}{*}{$\mathrm{p}$-value } \\
\hline & $\mathbf{n}$ & $\%$ & $\mathrm{n}$ & $\%$ & & \\
\hline \multicolumn{7}{|l|}{ Raised by biological or social mother } \\
\hline Yes & 382 & 88.6 & 796 & 92.8 & 1.00 & 0.012 \\
\hline No & 49 & 11.4 & 62 & 7.2 & $1.64(1.11-2.44)$ & \\
\hline \multicolumn{7}{|l|}{ Loss of biological mother } \\
\hline No & 421 & 97.7 & 827 & 96.4 & 1.00 & 0.212 \\
\hline Yes & 10 & 2.3 & 31 & 3.6 & $1.57(0.76-3.24)$ & \\
\hline \multicolumn{7}{|l|}{ Schooling of adolescent's mother } \\
\hline Complete primary or greater & 143 & 35.9 & 314 & 38.8 & 1.00 & 0.331 \\
\hline Never attended school or incomplete primary & 255 & 64.1 & 495 & 61.2 & $1.13(0.88-1.45)$ & \\
\hline \multicolumn{7}{|l|}{ Lived from 10 to 14 years of age with } \\
\hline One or both parents & 334 & 81.5 & 742 & 89.2 & 1.00 & $<0.001$ \\
\hline Others & 76 & 18.5 & 90 & 10.8 & $1.87(1.34-2.61)$ & \\
\hline \multicolumn{7}{|l|}{ Principal caregiver } \\
\hline One or both parents & 354 & 82.1 & 722 & 84.3 & 1.00 & 0.311 \\
\hline Other family members or others & 77 & 17.9 & 134 & 15.7 & $1.17(0.86-1.59)$ & \\
\hline \multicolumn{7}{|l|}{ Experience caring for other children } \\
\hline No & 147 & 34.1 & 380 & 44.3 & 1.00 & $<0.001$ \\
\hline Yes & 284 & 65.9 & 478 & 55.7 & $1.53(1.20-1.95)$ & \\
\hline \multicolumn{7}{|l|}{ Age of adolescent's mother at first childbirth (years) } \\
\hline $12-17$ & 196 & 48.8 & 290 & 38.3 & $1.53(1.19-1.95)$ & $<0.001$ \\
\hline$\geq 18$ & 206 & 51.2 & 673 & 61.7 & 1.00 & \\
\hline \multicolumn{7}{|l|}{ Siblings with children before 20 years of age } \\
\hline No & 244 & 58.5 & 580 & 69.8 & 1.00 & $<0.001$ \\
\hline Yes & 173 & 41.5 & 251 & 30.2 & $1.63(1.28-2.09)$ & \\
\hline
\end{tabular}

95\% Cl: 95\% confidence interval; OR: odds ratio.

in which society assigns specific roles to men and women. In Western culture, women are responsible for learning and performing activities related to the household, such as caring for the home and raising the children. Meanwhile, men are assigned the tasks of supporting and protecting the family 40 .

In low-income groups, although young people of both sexes begin working as teenagers, the meanings assigned to work are not the same, differing according to the expectations and representations of social gender roles. For women, one such role is motherhood. From an early age, young girls are prepared to be mothers, learning to care for the home and the younger siblings 41,42 . In addition, familiarity with taking care of other children makes motherhood a possible life project. Caring for siblings and other children assesses the girl's capacity to fulfill her role, reinforcing her socialization. In this sense, the skills she acquires contribute to her predisposition to have her own children 43 . In addition, the culture of motherhood becomes a valued factor in certain socio-cultural and economic settings 44 .

As for trans-generational factors, the literature shows that maternal history of teenage pregnancy is associated later on with early pregnancy in daughters 5,45. This association did not appear among the participants in the current study. However, there was a higher probability of motherhood among adolescent girls whose siblings also had children before age 20 . The literature approaches siblings' early motherhood/fatherhood as a potential risk factor for early motherhood. The phenomenon could be interpreted as a possible strengthening of fraternal ties in families where the parents are more absent, and where older siblings are responsible for caring for the younger 19,20,21,22. 
Use of tobacco, alcohol, and other drugs by adolescent girls with and without children and by their family members. Porto Alegre, Rio Grande do Sul State, Brazil, 2009.

\begin{tabular}{|c|c|c|c|c|c|c|}
\hline \multirow[t]{2}{*}{ Substance use } & \multicolumn{2}{|c|}{ Cases $(\mathrm{N}=431)$} & \multicolumn{2}{|c|}{ Controls $(\mathrm{N}=858)$} & \multirow[t]{2}{*}{ OR $(95 \% \mathrm{Cl})$} & \multirow[t]{2}{*}{ p-values } \\
\hline & $\mathbf{N}$ & $\%$ & $\mathbf{n}$ & $\%$ & & \\
\hline \multicolumn{7}{|l|}{ Tried smoking } \\
\hline No & 200 & 46.5 & 575 & 67.3 & 1.00 & $<0.001$ \\
\hline Yes & 230 & 53.5 & 279 & 32.7 & $2.37(1.86-3.00)$ & \\
\hline \multicolumn{7}{|l|}{ Tried drinking } \\
\hline No & 77 & 17.9 & 216 & 25.4 & 1.00 & 0.002 \\
\hline Yes & 352 & 82.1 & 633 & 74.6 & $1.55(1.16-2.08)$ & \\
\hline \multicolumn{7}{|l|}{ Ever arrived home intoxicated } \\
\hline No & 267 & 62.2 & 672 & 78.3 & 1.00 & $<0.001$ \\
\hline Yes & 162 & 37.8 & 186 & 21.7 & $2.19(1.70-2.82)$ & \\
\hline \multicolumn{7}{|c|}{ Family's reaction if arrived home intoxicated } \\
\hline Would realize and would be upset & 221 & 87.7 & 651 & 95.5 & 1.00 & $<0.001$ \\
\hline Would not realize or would not care & 31 & 12.3 & 31 & 4.5 & $2.94(1.75-4.95)$ & \\
\hline \multicolumn{7}{|l|}{ Tried illegal drugs } \\
\hline No & 397 & 92.3 & 830 & 96.8 & 1.00 & $<0.001$ \\
\hline Yes & 33 & 7.7 & 27 & 3.2 & $2.55(1.51-4.30)$ & \\
\hline \multicolumn{7}{|c|}{ Someone in the family with alcohol problems } \\
\hline No & 181 & 42.5 & 422 & 49.6 & 1.00 & 0.016 \\
\hline Yes & 245 & 57.5 & 429 & 50.4 & $1.33(1.05-1.68)$ & \\
\hline \multicolumn{7}{|l|}{ Someone in the family with drug problems } \\
\hline No & 266 & 62.9 & 573 & 67.3 & 1.00 & 0.114 \\
\hline Yes & 157 & 37.1 & 278 & 32.7 & $1.21(0.95-1.55)$ & \\
\hline
\end{tabular}

95\% Cl: 95\% confidence interval; OR: odds ratio.

As for substance use, in this study, having tried smoking was associated with adolescent motherhood. No studies were found in the literature showing a direct association between history of smoking and adolescent motherhood, but the results of the current study refer to the family context. A study in Santo André, São Paulo State, aimed at assessing the profile of adolescents that tried smoking showed the influence of the social and family setting as a significant factor 11. In a study in Gravataí, Rio Grande do Sul State, among adolescents that had tried smoking at least once, $34.8 \%$ reported smoking at home. Some $58.6 \%$ of students that had tried smoking reported that at least one of their parents smoked, and this association was statistically significant 32. In Brazilian National Survey on Schoolchildren's Health (PENSE), 1.3\% of the interviewees replied that their parents would not care if they knew they smoked 46 . In this sense, the family can be identified as a facilitator for smoking and an environment that can fail to protect against an unhealthy lifestyle, where early motherhood can be the outcome. The same is true for alcohol, considering the variable on having arrived home intoxicated.

The consumption of high amounts of alcohol (as in intoxication), due to its effect on consciousness, poses an increased risk of unprotected sex. An exploratory study of six university students from different socioeconomic strata in Bogotá, Colombia, showed that alcohol was present at the moment of conception, preventing the recognition of a risk situation for unwanted pregnancy. In addition, in their life histories, the young women displayed vulnerability as expressed by absence of parental authority, negative communication, conflictive family relations, permissiveness towards alcohol consumption, exposure to persons that consumed alcohol, easy access to alcoholic beverages, emotional needs, and experience with unequal gender values 29 . A population-based study of university students in Bogotá showed that $70 \%$ consumed alcohol, and that $30 \%$ admitted having had unplanned sexual relations while under the influence 47 .

Although alcohol consumption by adolescent girls can lead to a decrease in contracep- 
Hierarchical model of demographic, family, and lifestyle factors related to consumption of tobacco, alcohol, and other drugs associated with adolescent motherhood. Cases $(n=431)$, controls $(n=858)$. Porto Alegre, Rio Grande do Sul State, Brazil, 2009

\begin{tabular}{|c|c|c|}
\hline & OR $(95 \% \mathrm{Cl})$ & p-value \\
\hline \multicolumn{3}{|l|}{ Stage 1} \\
\hline \multicolumn{3}{|l|}{ Religion } \\
\hline Non-Catholic & 1.00 & 0.119 \\
\hline Catholic & $1.12(0.69-1.81)$ & \\
\hline None & $1.74(1.01-3.02)$ & \\
\hline \multicolumn{3}{|l|}{ Economic class * } \\
\hline B & 1.00 & 0.005 \\
\hline c & $3.29(1.57-6.92)$ & \\
\hline$D+E$ & $4.63(1.44-14.84)$ & \\
\hline \multicolumn{3}{|l|}{ Schooling } \\
\hline Middle School & 1.00 & 0.109 \\
\hline Primary School & $1.57(0.90-2.74)$ & \\
\hline \multicolumn{3}{|l|}{ Stage 2} \\
\hline \multicolumn{3}{|l|}{ Raised by biological or social mother } \\
\hline Yes & 1.00 & 0.264 \\
\hline No & $1.37(0.79-2.41)$ & \\
\hline \multicolumn{3}{|l|}{ Lived from 10 to 14 years with ** } \\
\hline One or both parents & 1.00 & 0.012 \\
\hline Others & $1.67(1.12-2.48)$ & \\
\hline \multicolumn{3}{|l|}{ Experience caring for other children ** } \\
\hline No & 1.00 & 0.011 \\
\hline Yes & $1.42(1.09-1.87)$ & \\
\hline \multicolumn{3}{|c|}{ Age of adolescent's mother at first childbirth (years) } \\
\hline $12-17$ & $1.25(0.96-1.63)$ & 0.103 \\
\hline$\geq 18$ & 1.00 & \\
\hline \multicolumn{3}{|c|}{ Siblings with children before 20 years of age ** } \\
\hline No & 1.00 & 0.001 \\
\hline Yes & $1.56(1.19-2.06)$ & \\
\hline \multicolumn{3}{|l|}{ Stage 3} \\
\hline \multicolumn{3}{|l|}{ Tried smoking } \\
\hline No & 1.00 & $<0.001$ \\
\hline Yes & $1.94(1.35-2.78)$ & \\
\hline \multicolumn{3}{|l|}{ Tried drinking } \\
\hline No & 1.00 & 0.914 \\
\hline Yes & $1.02(0.66-1.60)$ & \\
\hline \multicolumn{3}{|l|}{ Ever arrived home intoxicated } \\
\hline No & 1.00 & 0.011 \\
\hline Yes & $1.67(1.12-2.48)$ & \\
\hline \multicolumn{3}{|l|}{ Family's reaction if arrived home intoxicated } \\
\hline Would realize and would be upset & 1.00 & 0.073 \\
\hline Would not realize or would not care & $1.77(0.95-3.31)$ & \\
\hline \multicolumn{3}{|l|}{ Tried illegal drugs } \\
\hline No & 1.00 & 0.425 \\
\hline Yes & $1.37(0.63-2.98)$ & \\
\hline
\end{tabular}




\begin{tabular}{|c|c|c|}
\hline & OR $(95 \% \mathrm{Cl})$ & $\mathrm{p}$-value \\
\hline \multicolumn{3}{|l|}{ Stage 3} \\
\hline \multicolumn{3}{|c|}{ Family member with alcohol problems } \\
\hline No & 1.00 & 0.462 \\
\hline Yes & $1.14(0.81-1.60)$ & \\
\hline \multicolumn{3}{|c|}{ Family member with drug problems } \\
\hline No & 1.00 & 0.516 \\
\hline Yes & $1.12(0.79-1.60)$ & \\
\hline
\end{tabular}

95\% Cl: 95\% confidence interval; OR: odds ratio.

* Variable selected for inclusion in second stage of hierarchical regression;

** Variables selected for third stage of hierarchical regression.

tive precautions, this behavior can be used as a lifestyle indicator and a symptom of dissatisfaction with family relations 29,48 . Thus, alcohol consumption is present in unprotected sexual behavior, with its roots in the primary socialization context. Children and adolescents tend to learn values, habits, and attitudes based on their family experiences 29 .

According to Schenker \& Minayo 24, parents who talk with their children since early childhood and that succeed in establishing clear limits over the course of their upbringing build a strong protective net against the consumption of psychoactive substances during adolescence. Thus, young people with greater support and that feel understood by their families show lower use of tobacco, alcohol, and other drugs ${ }^{10}$. The configuration of factors associated with adolescent motherhood demonstrates the importance of family ties, social support, transmission of family values and parenting styles, both directly and indirectly by means of the control and supervision of alcohol and tobacco consumption in relation to early pregnancy.
The sample of 431 cases and 858 neighborhood controls allowed greater homogeneity between cases and controls. However, the study's results cannot be generalized to adolescents from higher social classes, since the majority of the girls belonged to classes C, D, and E. Another limitation that may have affected the results is recall bias, which influences the precision of responses referring to events in the past. In addition, the fact that the questionnaire was completed at the adolescent's home, often in the presence of some family member, may have influenced the girls' answers.

Family psychosocial characteristics represent the context in which tobacco and alcohol-related behaviors emerge. Greater attention should thus be given to family relations as risk or protective factors for substance use and adolescent motherhood. The study's findings as a whole indicate a public health problem that needs to be dealt with through targeted policies for adolescent girls and their families. 


\section{Resumen}

El objetivo del estudio fue estudiar la asociación entre factores demográficos, características psicosociales familiares, consumo de tabaco, alcohol y otras drogas y el embarazo en la adolescencia. Estudio de caso-control con 431 adolescentes de edades comprendidas entre los 14 y los 16 años de Porto Alegre, Rio Grande do Sul, Brasil, que dieron a luz en 2009 (casos) y 862 adolescentes sin hijos (controles). La regresión logística jerárquica se realizó en tres etapas. Variables demográficas, psicosociales, familiares y de estilo de vida. La menor inserción económica, no haber vivido con los padres entre 10 y 14 años (OR = 1,67; IC95\%: 1,12-2,48), la experiencia en el cuidado de niños (OR = 1,42; IC95\%: 1,09-1,87), hermanos que tuvieron hijos antes de los 20 años (OR $=1,56$; IC95\%: 1,19-2,06), el hecho de haber probado el tabaco $(O R=1,94$; IC95\%: 1,35-2,78) y el que ya hayan vuelto a casa embriagadas $(O R=1,67$; IC95\%: 1,12-2,48) se asoció con el embarazo en la adolescencia. Se debe prestar una mayor atención en las relaciones familiares al consumo de tabaco y alcohol y se debe tener en consideración que su uso se asocia al embarazo en la adolescencia.

Embarazo en Adolescencia; Consumo de Bebidas Alcohólicas; Hábito de Fumar; Drogas Ilícitas

\section{References}

1. Silva DV, Salomão NMR. A maternidade na pers pectiva de mães adolescentes e avós maternas dos bebês. Estud Psicol (Natal) 2003; 8:135-45.

2. Yazlle ME, Diógenes H. Gravidez na adolescência. Rev Bras Ginecol Obstet 2006; 28:443-5.

3. Coley RL, Chase-Lansdale PL. Adolescent pregnancy and parenthood: recent evidence and future directions. Am Psychol 1998; 53:152-66.

4. Bane MJ, Ellwood DT. Slipping into and out of poverty: the dynamics of spells. J Human Resour 1986 21:1-23.

5. Amorim MMR, Lima LA, Lopes CV, Araújo DKL, Silva JGG, César LC, et al. Fatores de risco para a gravidez na adolescência em uma maternidadeescola da Paraíba: estudo caso-controle. Rev Bras Ginecol Obstet 2009; 31:404-10.

6. Ministério da Saúde. Marco Legal Saúde: um direito de adolescentes. Brasília: Ministério da Saúde 2005.

7. Chalem E, Mitsuhiro S, Ferri CP, Barros MCM, Guinsburg R, Laranjeira R. Gravidez na adolescência: perfil sócio-demográfico e comportamental de uma população da periferia de São Paulo, Brasil. Cad Saúde Pública 2007; 23:177-86.

\section{Contributors}

C. S. Faler participated in the study design, data collection, analysis, and interpretation, and critical revision of the article. S. G. Camara, G. G. Alves, D. R. G. C. Aerts, and J. U Béria collaborated in the study design, data interpretation, critical revision of the article, and final approval for publication.

\section{Acknowledgments}

The authors wish to thank the CNPq funding agency, the research team of the Graduate Studies Program in Public Health at Universidade Luterana do Brasil (ULBRA-Canoas), the coordinator of the fieldwork, and the field interviewers.
8. Figueiró AC. Condições de vida e saúde reprodutiva de adolescentes residentes na comunidade de Roda de Fogo, Recife. Rev Bras Saúde Matern Infant 2002; 2:291-302.

9. Piccinini CA, Marin AH, Alvarenga P, Lopes RCS, Tudge JR. Responsividade materna em famílias de mães solteiras e famílias nucleares no terceiro mês de vida da criança. Estud Psicol (Natal) 2007; 12:109-17.

10. Paiva FS, Ronzani TM. Estilos parentais e consumo de drogas entre adolescentes: revisão sistemática. Psicol Estud 2009; 14:177-83.

11. Oliveira HF, Martins LC, Reato LFN, Akerman M. Fatores de risco para uso do tabaco em adolescentes de duas escolas do município de Santo André, São Paulo. Rev Paul Pediatr 2010; 28:200-7.

12. Carvalho GM, Barros SMO. Fatores psicossociais relacionados à gravidez na adolescência. Acta Paul Enferm 2000; 13:9-17.

13. Ximenes Neto FRG, Dias MAS, Rocha J, Cunha ICKO. Gravidez na adolescência: motivos e percepções de adolescentes. Rev Bras Enferm 2007; 60:279-85. 
14. Sousa MCR, Gomes KRO. Conhecimento objetivo e percebido sobre contraceptivos hormonais orais entre adolescentes com antecedentes gestacionais. Cad Saúde Pública 2009; 25:645-54.

15. Villela WV, Doreto DT. Sobre a experiência sexual dos jovens. Cad Saúde Pública 2006; 22:2467-72.

16. Gigante DP, Barros FC, Veleda R, Gonçalves H, Horta BL, Victora CG. Maternidade e paternidade na coorte de nascimentos de 1982 a 2004-5, Pelotas, RS. Rev Saúde Pública 2008; 42 Suppl 2:42-50.

17. Silva L, Tonete VLP. A gravidez na adolescência sob a perspectiva dos familiares: compartilhando projetos de vida e cuidado. Rev Latinoam Enferm 2006; 14:199-206.

18. Cunha VS, Wendling MI. Aspectos transgeracionais da gravidez na adolescência na perspectiva de mães e filhas residentes em Parobé e Taquara (RS). Contextos Clínicos 2011; 4:28-41.

19. Miller BC, Benson B, Galbraith KA. Family relationships and adolescent pregnancy risk: a research synthesis. Dev Rev 2001; 21:1-38.

20. Persona L, Shimo AKK, Tarallo MC. Perfil de adolescentes com repetição da gravidez atendidas num ambulatório de pré-natal. Rev Latinoam Enferm $2004 ; 12: 745-50$.

21. Santos A, Carvalho CV. Gravidez na adolescência: um estudo exploratório. Bol Psicol 2006; 56:135-51.

22. Melo MT. Estar grávida na adolescência: um estudo realizado no Hospital Regional de São José - SC. Psicol Soc 2001; 13:93-106.

23. Balaguer I, Castillo I, Pastor Y. Los estilos de vida relacionados con la salud en la adolescencia temprana. In: Balaguer I, editor. Estilos de vida en la adolescencia. Valencia: Promolibro; 2002. p. 5-26.

24. Schenker M, Minayo MC. Risk and protective factors and drug use among adolescence. Ciênc Saúde Coletiva 2005; 10:707-17.

25. Guimarães ABP, Hochgraf PB, Brasiliano S, Ingberman YK. Aspectos familiares de meninas adolescentes dependentes de álcool e drogas. Rev Psiquiatr Clín 2009; 36:67-74.

26. Moreno RS, Ventura RN, Bretas JRS. Ambiente familiar e consumo de álcool e tabaco entre adolescentes. Rev Paul Pediatr 2009; 27:354-60.

27. Figlie N, Fontes A, Moraes E, Paya R. Filhos de dependentes químicos com fatores de risco bio-psicossociais: necessitam de um olhar especial? Rev Psiquiatr Clín 2004; 31:53-62.

28. Scholte RHJ, Poelen EAP, Willemsen G, Boomsma DI, Engels RCME. Relative risks of adolescent and young adult alcohol use: the role of drinking fathers, mothers, siblings, and friends. Addict Behav 2008; 33:1-14.

29. Alvarez ML. Gravidez precoce de estudantes de enfermagem e o consumo de álcool. Rev Latinoam Enferm 2008; 16(n. spe):577-83.

30. Anteghini M, Fonseca H, Ireland M, Blum RW. Health risk behaviors and associated risk and protective factors among Brazilian adolescents in Santos, Brazil. J Adolesc Health 2001; 28:295-302.

31. Heilborn ML, Aquino EML, Bozon M, Knauth DR. O aprendizado da sexualidade: reprodução e trajetórias sociais de jovens brasileiros. Rio de Janeiro: Editora Fiocruz/Garamond; 2006.
32. Vieira PC, Aerts DRGC, Freddo SL, Bittencourt A, Monteiro L. Uso de álcool, tabaco e outras drogas por adolescentes escolares em município do Sul do Brasil. Cad Saúde Pública 2008; 24:2487-98.

33. Caputo VG, Bordi IA. Teenage pregnancy and frequent use of alcohol and drugs in the home environment. Rev Saúde Pública 2008; 42:402-10.

34. Gallo AE, Willams LCA. Escola como fator de proteção à conduta infracional de adolescentes. Cad Pesqui 2008; 38:41-59.

35. Duarte CM, Nascimento VB, Akerman M. Adolescent pregnancy and social exclusion: analysis of intra-urban disparities. Rev Panam Salud Pública 2006; 19:236-43.

36. Kassar SB, Lima MC, Albuquerque MFM, Barbieri MA, Gurgel RQ. Comparações das condições socioeconômicas e reprodutivas entre mães adolescentes e adultas jovens em três maternidades públicas de Maceió, Brasil. Rev Bras Saúde Matern Infant 2006; 6:397-403.

37. Simões VM, Silva AA, Bettiol H, Lamy-Filho F, Tonial SR, Mochel EG. Características da gravidez na adolescência em São Luís, Maranhão. Rev Saúde Pública 2003; 37:559-65.

38. Silveira ALSS, Blay SL. Mães adolescentes em situação de rua: uma revisão sistemática da literatura. Rev Psiquiatr Rio Gd Sul 2010; 32:3-15.

39. Nunes ELG, Andrade AG. Adolescentes em situação de rua: prostituição, drogas e HIV/AIDS em Santo André, Brasil. Psicol Soc 2009; 21:45-54.

40. Strey MN. Gênero. In: Guareschi P, organizador. Psicologia social contemporânea. Petrópolis: Editora Vozes; 1998. p. 181-98.

41. Sarti CA. A família como espelho: um estudo sobre a moral dos pobres. São Paulo: Autores Associados; 1996.

42. Paim HHS. Marcas no corpo: gravidez e maternidade em grupos populares. In: Duarte LFD, Leal OF, organizadores. Doença, sofrimento e perturbação: perspectivas etnográficas. Rio de Janeiro: Editora Fiocruz; 1998. p. 31-47.

43. Pantoja F, Bucher J. Adolescentes grávidas: vivencias de uma nova realidade. Psicol Ciênc Prof 2007; 27:510-21.

44. Lira BNR, Cabral IE. A maternidade na adolescência e a problemática do cuidado à criança prematura: um estudo de revisão. Revista da Sociedade Brasileira de Enfermeiros Pediatras 2007; 7:41-8.

45. Feijó MC, Assis SG. O contexto de exclusão social e de vulnerabilidades de jovens infratores e de suas famílias. Estud Psicol 2004; 9:157-66.

46. Instituto Brasileiro de Geografia e Estatística. Pesquisa Nacional por Amostra de Domicílios. v. 30. Rio de Janeiro: Instituto Brasileiro de Geografia e Estatística; 2009.

47. Unidad Coordinadora de Prevención Integral. Factores asociados al uso de drogas en la población universitaria de Bogotá: documento final. Bogotá: Alcaldía Mayor; 2003.

48. Jessor R. Successful adolescent development among youth in high-risk settings. Am Psychol $1993 ; 48: 117-26$.

Submitted on $23 / \mathrm{Jul} / 2012$

Final version resubmitted on $17 / \mathrm{Jan} / 2013$

Approved on 31/Jan/2013 